\title{
The Limitation of the Right to Assembly and the Right to Movement in Order to Fulfil the Right to Health of Society in the Covid-19 Pandemic in Indonesia
}

\author{
Erna Ratnaningsih ${ }^{1}$, Siti Yuniarti ${ }^{2}$ \\ ${ }^{1,2}$ Business Law Department, Bina Nusantara University, Jakarta Barat, Indonesia \\ I'ernarn@binus.ac.id. ${ }^{2}$ yuniarti@binus.ac.id
}

\begin{abstract}
The Corona Covid-19 virus has officially known as a global pandemic by World Health Organization (WHO). Many countries have other ways to avoid the spread of Covid-19 such as the prohibition of people to assemble, the limitation of activities in public places/facilities, social distancing and lock down. These state policies have implications for restrictions on human rights including the right to assemble and the right to movement in order to accomplish public health right. The research is normative and using secondary data. The paper results from the right of assembly, the right of movement, the right of health are guaranteed as derogable rights in Indonesia Constitution. It obtains restrictions on the right to assemble and the right to movement in the context of tackling the global academic Covid-19 can be justified in the Indonesian constitution. However, the limitation of human in handling Covid-19 in the regulations does not refer to Article 12 of the 1945 Constitution that regulate state emergency to restrict the right to movement and the right to assembly. Parliament and the government should amend the regulation to protect human rights in the time of emergency, to restrict further human rights without discrimination.
\end{abstract}

Keywords: the limitation of the rights to assembly/movement, the fulfilment of the rights to health, Covid-19 pandemic

\section{INTRODUCTION}

Corona virus (Covid-19) has been announced by the World Health Organization (WHO) as a worldwide pandemic as the prompt and enormous spread of the virus on 11 March 2020. Data on global distribution of countries infected with the Corona virus based on WHO on 4 December 2020, there have been $64,350,473$ confirmed cases of Covid-19 and 1,494,668 death [1]. The situation of Covid-19 virus in Indonesia, data from the Covid-19 of Gugus Tugas Percepatan Penanganan Covid-19 (Task Force for the Acceleration of Handling Covid-19) by the Government established 563,680 confirm case, 80,023 active cases, 466,178 recovered and 17,479 death [2]. Considering the importance of preventing the spread of the virus globally, the WHO wrote a letter to President Joko Widodo to take measures to prevent the virus from spreading in Indonesia. The letter was signed by WHO Director General Thedros Adhanom and sent to Jokowi on March 10, 2020, which gave several suggestions including improving the emergency response mechanism, to immediately establish a national emergency status. WHO also recommends that the government actively educates and communicates by implementing appropriate risk communication and involving the community participation [3]. In this case, WHO assesses the importance of special handling of public health emergencies by the Indonesian government because of its enormous impact on human life.

The fulfillment of human rights is threatened that it cannot be fulfilled, especially the right to life and the right to health during the Covid-19 pandemic. The human rights are mutual as the linkage of one right to another shows how important it is to pay attention to one right to another. The advancement of civil and political rights during the Covid-19 pandemic has become a fact as the basis for the fulfillment of other human rights. In a democratic life of society, it is important to uphold the right to life and health. However, on the other hand, it shows a connection with the right to life and the right to health with other rights. Health attempts carried out during a pandemic are the enforcement of social distancing which is effective in preventing the spread of diseases including Covid-19 [4].

In order to prevent further spread of the virus in various countries have policies differently in the implementation of public health emergencies including Indonesia. Emergency conditions are stated in Indonesia Constitution. The president has the right to declare the state of emergency (Article 12 of Indonesia Constitution). The president also has rights to the issue government regulation in lieu of law if the state in a crisis situation (Article 22 of Indonesia Constitution). However there are no 
regulations refer to Article 12 of Indonesia Constitution to prevent spread of Covid-19. Indonesia has enacted regulations that lead to the protection and fulfillment of public health for the public interest, such as closing schools and work and other social distancing policies. The impact of closing work, schools and other social distancing lead to the limitation of human rights namely the right to assembly and the right to movement. For these reasons, this study will examine the right to health, the right to assembly and the right to movement are guaranteed in the constitution. It will analyze whether the fulfillment of specific human right (the right to health) by restricting the right to freedom of assembly and movement is justified in the constitution and in the principles of international law. How the freedom of assembly and freedom of movement base on the Indonesian Constitution, legislation and the principle of human rights law can be limited by the state.

\section{METHOD}

Normative legal research that is a study of legal principles, legal systematics, law synchronization, legal history and legal comparison [5]. This research was conducted through normative legal research by examining and analyzing the constitution and regulations relating to the right to assembly, the right to movement and the right to health and human rights. The research approach used in the discussion and problem solving through a statutory approach and a conceptual approach. Normative research certainly has to use a legislative approach because what will be examined are various legal rules, which are the focus as well as the central theme of a study. The conceptual approach is applied to carry up objects that attract attention from the point of view of the practical and the perspective of knowledge in certain attributes [6]. The statutory approach is accomplished by examining and analyzing the protection of human rights, namely the right to assembly, the right to movement and the right to health in the constitution. In addition, it reviews and analyses laws and regulations that limit the right to assembly, the right to move in order to fulfill the right to public health. Meanwhile, the conceptual approach is used in studying and analyzing the concepts of human rights protection, the limitations of human rights that are allowed in the provision of international law that has been ratified by Indonesia.

Normative legal research uses secondary data or data obtained through decision materials obtained through primary legal materials such as constitution and statutory regulations. Also through secondary legal materials from reference books, journals related to the protection of human rights during a pandemic, human rights restrictions. The next steps to manage the research by collecting data from books, national and international journals, legislation and data from the internet which are divided into categories. These data will be reviewed to answer the research problems. Then the data can be analyzed based on the Indonesian Constitution and legislation and also International legal concepts to address legal issues.

\section{DISCUSSION}

\subsection{The right to health, the right to assembly and the right to movement in the constitution and regulations in Indonesia}

Many countries have different policies in handling the spread of Covid-19. Some of policies to reduce the transmission and impact the Covid-19 are to implement large-scale and public health measures including quarantine and individual movement. These policies should be implemented in a comprehensive manner between public health and social measures. WHO states countries must act in accordance with Article 3 of the International Health Regulation (2005) which takes into account respect for the dignity, human rights and fundamental freedoms of persons. The human rights issues during the Covid-19 pandemic were further elaborated on the two UN Committee on Economic, Social and Cultural Rights, General Comment 14 (2000) and International Covenant on Civil and Political Rights (ICCPR) (1976) and further elaborated in the Siracusa Principles (1984) [7]. Human rights considerations during the Covid-19 pandemic were further elaborated on in the two UN Committees.

The element of human rights is to ensure protection for the basic rights of citizens in the constitution. In the development of history, human rights are always associated with the Constitution. According to the constitutionalism concept, the limitation and regulation of state power are intended as protection, respect and fulfillment of human rights. Human rights are significant to the modern state constitution [8]. Relating to the theory of constitutional government or constitutionalism, in the constitution must be written explicitly and in detail the articles of human rights. The state has obligations in respecting, protecting and fulfilling the human rights of citizens. This is consistent with the framework of the formulation of Human Rights of the United Nations (UN) and other international 
human rights documents. The limitation of government power is enacted in the constitution. State power cannot itself limit normatively. However, the people can judge, demand their rights secured by the constitution to the state [9].

In relation to Covid-19, there are at least 3 (three) human rights in Indonesia Constitution affected by the Covid-19 pandemic namely:

1. "Everyone has the right to freedom of association, assembly and expression" (Article $28 \mathrm{E}$ paragraph 3 of the 1945 Constitution of the Republic of Indonesia);

2. "Everyone is free to embrace religion and worship according to their religion, choose education and teaching, choose work, choose citizenship, choose a place to live in and out the territory of the country, and has the right to return" (article 28E paragraph (2) of the 1945 Constitution of the Republic of Indonesia NRI 1945);

3. "Everyone has a right to live in physical and spiritual prosperity, to live and to have a good and healthy living environment and the right to obtain health services".

In the Indonesia Constitution, non-derogable rights are regulated in article 28I of the 1945 Constitution which states "the right to life, the right not to be tortured, the right to equality before the law, the right to freedom of though and conscience, religion right, the right not to be prosecuted on a retroactive basis is a human right that cannot be reduced under any circumstances". The right of assembly and the right of movement and the right to health do not list in non-derogable rights. Therefore, it can conclude that these rights are derogable rights. Meanwhile, the right to health is located in the International Covenant on Economic, Social and Cultural Rights that emphasizes the fulfilment of basic human rights.

In addressing the spread of Covid-19, the Indonesia Government enacted same regulations, namely, the Government has implemented a law namely Law No. 24 of 2007 concerning Disaster Management which can be classified as a Covid-19 as a non-natural disaster, Law Number 6 of 2008 concerning Health Quarantine, Law Number 2 of 2020 regarding Stipulation of Peraturan Pemerintah Pengganti Undang-Undang/Perpu (Government Regulation in Lieu of Acts) Number 1 of 2020 and other derivative regulations. Firstly, determination of emergencies is regulated through Law Number 24 of 2007 concerning Disaster Management regulates non-natural disasters are disasters caused by events or a series of non-natural events which include technology failure, modernization, epidemic and disease outbreaks (Article 1 paragraph 3). In the implementation of disaster management (in this case Covid-19), the government can designate disasterprone areas to be prohibited areas for settlement or revoke or reduce part or all of the ownership rights of each person to an object in accordance with statutory regulations (Article 32 paragraph (1)). The implementation of disaster management during emergency response includes: rapid and precise assessment of the location, damage and resources, determination of the status of a disaster emergency, rescue and evacuation of the affected community, fulfilment of basic needs, protection of vulnerable groups and recovery with vital infrastructure and facilities (Article 48). Determination of emergency status is strengthened by Presidential Decree No. 11 of 2020 relating to the establishment of Corona Virus Disease 2019 (COVID-19) Public Health Emergency on March 31, 2020.

Secondly, restrictions on the right to assemble and move in Indonesia are based on Law Number 6 of 2018 concerning Health Quarantine, which defines public health emergencies as extraordinary public health events marked by the spread of infectious diseases and / or events caused by nuclear radiation, biological pollution, chemical contamination, bioterrorism and food that cause health hazards and potentially spread across regions or across countries. This law provides several alternative countermeasures for the emergence of a public health emergency situation, which is conducted through house quarantine, regional quarantine, hospital quarantine or Large Scale Social Restrictions (Pembatasan Sosial Berskala Besarl $P S B B)$. The government established the PSBB on March 31, 2020 compared to other alternative restrictions, namely limiting certain activities of the population in an area suspected of being infected with the disease and / or contaminated in such a way as to prevent the possibility of spreading the disease or contamination. In the $P S B B$, the restrictions carried out according to Article 59 Paragraph (3), at least include: a. school and workplace entertainment; b. restrictions on religious activities; and / or c. restrictions on activities in public places or facilities. Meanwhile, if the choice is to quarantine the area is not stated restrictions on religious activities, but there is the responsibility of the central government to meet the basic living needs of people and animal feed in quarantine areas.

As an implementation of the rules derived from this Act Government Regulation Number 21 of 2020 regarding the Guidelines for Large-Scale Social 
Restrictions. These restrictions are certain activities of residents in an area suspected of having Covid-19 to prevent its spread. Restrictions on the movement of people or goods can be carried out by local government with approval of Minister of Health. Large Scale Social Restrictions include the closure of schools and workplaces, the issue of activities in public space, public and private transportation systems and other limitations in the issue of defence and security of the country. The implementation of $P S B B$ raises the pros and cons, the Jakarta Legal Aid Institute states that the Health Quarantine Act 2018 explicitly stipulates that the quarantine actions / policies cover 4 namely homes quarantine, hospital quarantine, regional quarantine and large-scale social restrictions. The Government regulation that should be issued based on this law covers 4 matters, so that acts of quarantine can be performed systematically and consistently. Without it, the Indonesian government wants to maneuver by implementing the PSPB only, because it does not want to bear the fulfillment of the basic needs of citizens and livestock where the fulfillment of these rights is in the area quarantine action scheme, house quarantine and hospital quarantine [10].

Thirdly, regulations relating to financial support to deal with the Covid-19 pandemic, namely Government Regulation in Lieu of Law (Perpu) Number 1 of 2020 concerning State Financial Policy and Financial System Stability for Handling Corona Virus Disease 2019 (Covid- 19) and / or in the context of handling Threats using the National Economy and / or Financial System Stability. The government has stipulated for handling public health, funding support by providing a social safety net for affected communities and economic recovery (business). The legal basis for the formation of the Perpu refers to Article 22 of the 1945 Constitution of the Republic of Indonesia in the event that there are circumstances that compel the President to have the right to stipulate regulations as a government as law with the requirement to obtain the approval of the House of Representatives at the following session period which is then ratified as Law Number 2 of 2020 concerning the Stipulation of Perpu Number 1 of 2020 into law has been passed by the DPR and signed by President Joko Widodo on May 16,2020 [11].

The government's action to issue a Регpu has sparked a legal debate whether the Covid-19 emergency in Indonesia is the same as the state of emergency contained in Article 12 of the 1945 Constitution which states that the President states that the state of danger is determined by law. The only law that regulates the state of danger is Law Number 23 of 1959 concerning the Revocation of Law Number 74 of 1957 regarding a state of danger. Meanwhile, what is regulated in Article 22 paragraphs (1) of the 1945 Constitution that state in a compelling emergency, the President is entitled to stipulate a Perpu. An urgent need or a state of danger is regulated in Article 12 of the Indonesian Constitution that states that the President. Legal considerations in Law Number 2 of 2020 do not mention Article 12 of the 1945 Constitution of the Republic of Indonesia as the legal basis for its formation. This law refers to Article 5 paragraph (1) of the Constitution, Article 20 of the Basic Law and Article 22 of the 1945 Constitution that basically states that the President has the right to propose a draft law and the Parliament has the authority to stipulate laws as well as the president. It reserves the right to issue government regulations in lieu of laws in urgent situations. The constitutional basis of this law is that the President has the right to submit a bill to the (Article 5 paragraph (1) of the Indonesian Constitution), the Parliament has the authority to enact laws, Each bill is discussed between the Parliament and the President (Article 20 of the Indonesian Constitution) and in In an urgent crisis situation, the President has the right to issue government regulations in lieu of laws in an urgent situation.

Law Number 2 of 2020 was passed because of the existence of economic growth that was threatened by the outbreak of the Covid-19 pandemic with a decrease in state revenues so that proper policies in the financial sector were needed. This urgent condition must be resolved immediately by making policies in the health sector, providing social safety nets to affect communities and economic recovery which must be carried out immediately. So that it takes a law that provides a legal basis for the government and related agencies to take policies and strategic steps in saving the economy in Indonesia. Furthermore, Law Number 6 of 2018 concerning Health Quarantine and Law No. 24 of 2007 concerning Disaster Management does not mention the situation of the state of emergency in the Article 12 of Indonesian Constitution.

According to Jimly Assidiqie, the situation has continued as a 'de-facto' emergency (emergency defacto) but not recognized as a 'de-jure' state of emergency. The implementation Article 12 of the 1945 Constitution is not properly due to historical trauma to implement Law Number 23 of 1959 concerning the State of Danger originating from the Perpu was originally formed in an atmosphere of war 
and armed conflict after the Presidential Decree July 5 , 1959. During the old and new order, emergencies were also often misused for the sake of power according to the interpretations of the authorities themselves [12]. Law No. 23 of 1959 concerning a state of danger in essence stipulating that the President has the authority to declare all or part of the territory of the Republic of Indonesia in a state of danger with the level of a civil emergency or a state of military emergency or a state of war or if it is threatened by rebellion, rioting or due to natural disasters, war, symptoms that could endanger the life of the country.

There are two problems in the formation of Law Number 23 of 1959. The first problem is that in the process of its formation, this law was established in an undemocratic political atmosphere and there is no checks and balances mechanism between executive power and legislative power. This is consistent with the opinion of George Crowder who stated "in which one exercise of power is reviewed by another". Therefore, formally the process of forming the law contradicts Article 22 of the 1945 Constitution. Another problem is in the formal aspect, it can be seen from a number of articles in Law Number 23 of 1959 which have the potential to seize a number of human rights of citizens such as confiscation, wiretapping and arrest of a person without going through adequate legal process. Therefore, when President Joko Widodo stated on March 31, 2020, there was an option to implement a civil emergency based on this law when it was rejected by a number of experts. Even though when referring to the constitution, this option is basically possible because the conditions that occur in the Covid-19 pandemic outbreak are an abnormal situation so that at a certain point the President must be forced to violate a number of provisions in the law such as diverting the budget for handling the Covid-19 pandemic outbreak. So that a number of human rights violations are intended to prevent the spread of the Covid-19 pandemic outbreak [13].

It can be seen that the government is implementing various policies as a form of accelerating the handling of Covid-19 and its economic impact. Although the policies implemented received different responses from the public. However, restrictions imposed by the government are enforced based on law. As the implementation of Article 12 of the Constitution, it should be amend Law Number 23 of 1959 as the implementation of Article 12 of the 1945 Constitution, which measures the determination of the state of danger, the requirements for the danger situation which provides protection and legal certainty for the public in carrying out their activities during an emergency. The state, in this case the central and regional governments, does not only make policies in regulating the spread of Covid through various human rights restrictions. However, the state also has an obligation to pay attention to the basic needs of society, namely food, clothing, shelter and health services.

\subsection{The limitation of the movement right and assembly right in the covid-19 pandemic}

Indonesia has ratified the International Covenant on Civil and Political Rights and the International Covenant on Economic, Social and Cultural Rights. In the covenant there are rights that can be largely limited for the purpose needed in a democratic society including for the benefit of public health. Human rights restrictions can be carried out in normal times, but the Covid-19 pandemic situation is a special situation. Limitation or reduction of human rights can be carried out in an emergency that threatens the life of the nation to take action that deviates from its legal obligations. This limitation is acceptable at the normal time. However, the Covid19 crisis is not a normal time. The Convention holds specific provisions that allow unilateral reduction of conventional rights contained in Article 15 on Civil and Political Rights (ICCPR), Article 27 (1) of the American Convention on Human Rights (ACHR) or article 4 of the Arab Charter of Human Rights. The only African Charter that does not regulate restrictions on human rights even the African Commission states that no abatement is possible. The reduction of human rights in emergency situations does not replace the permissible limits of human rights in state public policy. Under normal circumstances, the implementation of fundamental rights can be conflicting with the public interest, this is where the role of the state is to balance these two interests. It is acceptable to restrict and reduce human rights under extraordinary circumstances. The state is entitled to balance these interests and limit some of these rights if necessary. In exceptional circumstances, more severe restrictions and reductions are acceptable [14].

The exercise of certain political rights is specifically given restrictions, namely legislation concerning domestic order and security in their respective countries. For example in the Civil and Political Covenants it is determined that the right to peaceful assembly be subject to restrictions in accordance with national law and which in Article 
21 of UDHR democratic societies are needed in the interests of national security or public safety, public order, protection of health and public decency or protection of rights and the freedoms of others (Article 21 UDHR). In addition, Article 4 of the Civil and Political Covenant gives authority to States parties in emergencies that threaten the life of the nation and its existence reduces its obligations under this Covenant. However, special powers are in turn limited by the provision that there are some rights which must not be limited (non-derogable rights) [15]. Restrictions are made in handling COVID-19, especially the right of assembly and the right to move is not a non-derogable right therefore that the state can make restrictions.

The concept of a state of emergency has detailed requirements in the International Law Association's Paris Minimum Standards of Human Rights Norm in a State of Emergency (Paris Standards 1984). The declaration of a state of emergency should be for a fixed period defined by a constitution and that extension should be subject to a prior legislative approval. Hereafter, the Paris Standards should only cover that part of a state's territory actually affected and in doing so. States keep the right to extend the special scope of emergency as necessary [16]. The scope of limiting rights by the state is conducted by means of policy adjustments in order to minimize the potential impact on human rights. Some human rights norms that cannot be reduced under any circumstances, such as the prohibition of jus cogens against torture, slavery, and the deprivation of life or freedom arbitrarily. Other norms that can be reduced, such as the right to freedom and movement, expression and association if "to the extent really required by an emergency." The Siracusa Principle affects the implementation of the limitation and reduction of human rights in the ICCPR Principles. carried out by the state to suspend human rights during an emergency must be based on a valid legal basis, urgent public need, legitimate objectives, and proportionality. During an emergency, the state is obliged to obey human rights norms and can postpone it. If the actions undertaken by states must conform to human rights norms adhered to during an emergency and they can take into account the geographic and temporal scope of derogation as well as a substantive conception of proportionality requiring states to use only those measures that are minimally limiting $\mathrm{k}$ freedoms that are normally protected [17].

Research conducted by the International Commission of Jurists (ICJ) on the States of Emergency Involving fifteen international experts and numerous national studies has recommended that "in international law a state of emergency is selfdefence in criminal law. The idea of an emergency situation is to answer the need of the state. to defend oneself based on an unusual balance between collective interests and individual interests In particular, in human rights and civil liberties, exchanging human rights is seen as a concession to the extraordinary actions of the state that are inevitable in times of emergency and also as a means to control such action The restriction or reduction of rights is based on the balance of human rights with the common goal of public order and national security[18].

Indonesia has regulated in the constitution the authority to proclaim a state of danger (Article 12 of Constitution). However, in the implementation of the law used to prevent the spread of COVID-19 in Indonesia, there is no law base on Article 12. Law Number 23 of 1959 concerning the state of Jeopardy (danger) that referred to article 12 of the Constitution was denied by the public because it was repressive and often abused by the authorities to silence democracy. For this reason, Indonesia in the future need to amend this law by referring to the ICCPR, the Siracusa Principle and the Paris Standard in order to respect and safeguard human rights in the state of emergencies.

According to the Siracusa Principle, public health can be invoked as a basis for limiting certain rights so that the state takes steps related to the existence of serious threats to the health of residents or individual members of the community. Measures taken by states should be aimed at preventing disease or injury or providing care for those who are sick or injures. This is the basis for the provision on international health established by WHO. The definition of health is not only for the absence of disease or weakness but a complete physical, mental and social state. This broad concept fills the fields of social medicine and special fields such as the fields of mental health, education, nutrition, housing, health and welfare of mothers and children. Public health means public health in the broadest sense. The Black's Law Dictionary, public health as one of the objects of the authority of the State Police, meaning the health or sanitation conditions of the general public or the community in a mass. These three criteria have met the qualifications that in fulfilling the right to public health, the state can place restrictions on other rights such as the right to assembly and the right to move or move. WHO itself has declared that the Corona virus is a global 
pandemic. Restrictions imposed by a country must be constructed on the law.

The limitation on human rights in Indonesia has been regulated in Article 28J of Indonesia Constitution and must be implemented based on the law by taking into account moral values, religious values, security and public order in a democratic society. Although there are pros and cons to the enactment of the laws in terms of procedures and content as well as the policies used by the government to impose Large Scale Social Restrictions compared to other policy alternatives such as lock down. Legal mechanisms or procedures can be utilized to resolve these differences of opinion. The most important thing that must be underlined is that whatever efforts by the state in preventing the further spread of the Corona virus must be regulated by law. The law must base on article 12 of the constitution which regulates emergency situations. For this reason, in the future it is necessary to amend Law No. 23 of 1959 on state of emergency which is not in accordance with the development of society. This law will regulate the scope of the state of emergency, the duration of the emergency situation and the protection of human rights in an emergency situation.

\section{CONCLUSION}

The limitations of human rights by the state through freedom of assembly and freedom of movement in the face of the global pandemic COVID-19 can actually be justified by the Indonesian Constitution and international human rights law. During an emergency situation, the state may impose regulations or policies that are needed to protect legitimate interests, namely public health, which is of course temporary by limiting other human rights such as the right to assemble and move through Large Scale Social Restrictions designation by the Government of Indonesia. So, the limitation of rights is to prevent the spread of pandemic and it is a temporary not permanent limitation of rights. However, in principle, this restriction may be an instrument for abuse authority for personal or group interests. Its application must pay attention to minority communities, vulnerable people who cannot access the basic rights of their need. Limited human resources and funds from the Government, public participation in the community is needed to conduct the implementation of Large Scale Social Restrictions and avoid people who cannot fullfil the basic need.

In preventing the spread of Corona Virus, the Government has enacted numerous laws and also stipulated emergency conditions. In Indonesia, emergencies are the authority of the President which is regulated in Article 12 of the 1945 Constitution of the Republic of Indonesia. Descriptions of emergencies are contained in Law No. 23 of 1959 concerning the state of danger which is a legacy law of the New Order era which is still valid but not used in the corona pandemic because of the rejection of the people (public) who consider this law very repressive and limit the rights of citizens. For this reason, future amendments to the law on Emergencies are needed to regulate the elaboration of Article 12 of the 1945 Constitution of the Republic of Indonesia, which will govern the conditions and consequences of a state of emergency, the duration of an emergency, the protection of human rights and so on. Amendments to this law should be guided by or refer to international legal principles such as the ICCPR, Siracusa Principle and The International Law Association's Paris Minimum Standards of Human Rights Norms in a State of Emergency (Paris Standards 1984).

\section{REFERENCES}

[1] World Health Organization (2020, November 2020), Global situation of Coronavirus Diseases by World Health Organization, Retrieve from https://covid19.who.int

[2] Peta Sebaran Covid di Indonesia, (2020, November 2020) retrieved from https://covid19.go.id/peta-sebaran

[3] Tempo.com (2020, May 2020), retrieved from

https://nasional.tempo.co/read/1319323/ beredar-surat-who-minta-jokowi-seriustangani-corona-ini-isinya/full\&view=ok]

[4] Alessandra SPADARO, COVID-19, Testing the Limits of Human Rights, European Journal of Risk Regulation, Vol. 11:2, 2020, p.319, https://www.cambridge.org/core/journals /european-journal-of-riskregulation/article/covid19-testing-thelimits-of-humanrights/DED8334F9C1D793ACDB43054 A2A9F19C

[5] Soekanto, Soerjono. (2015). Pengantar Penelitian Hukum, Jakarta, Indonesia: UI Press.

[6] Ibrahim, Johnny. (2007) Teori dan Metodologi Penelitian Hukum Normatif. Malang, Indonesia: Bayumedia Publishing. 
[7] World Health Organization (2020, November 2020), Addressing Human Rights as Key to the Covid-19 Rensponse. Retrieve from

https://www.who.int/publications/i/item/ addressing-human-rights-as-key-to-thecovid-19-response]

[8] Asshiddiqie, Jimly. (2009). Menuju Negara Hukum yang Demokratis, Jakarta, Indonesia: Bhuana Ilmu Populer.

[9] Nasution, Adnan Buyung. (2007). Arus Pemikiran Konstitusionalisme: Hak Asasi Manusia dan Demokrasi, Jakarta, Indonesia: Kata Hasta Pustaka.

[10] Lembaga Bantuan Hukum Jakarta (2020, November 2020), Kertas Posisi, Penanganan Wabah Pandemi Covid-19 dan Penerapan PSBB di Jabodetabek Harus Memperhatikan Hak Asasi Manusia dan Pemenuhan Hak Warga, hlm. 8, retrieved from https://www.bantuanhukum.or.id/web/ca tatan-kritis-lbh-jakarta-penangananwabah-pandemi-virus-covid-19-danpenerapan-psbb-di-jabodetabek/

[11] Kemenkeu (2020, November 2020) Perpu No. 1/2020 Disahkan Jadi UndangUndang, Retrieve from https://www.kemenkeu.go.id/publikasi/b erita/perppu-no12020-disahkan-jadiundangundang/

[12] Asshiddiqie, Jimly. (2020). Konstitusi \& Pandemi Covid-19, disampaikan dalam kuliah umum on line yang diselenggarakan oleh Fakultas Hukum Universitas Surabaya \& Jimly School of Law and Government (JSLG) Surabaya, 23 April 2020.

[13] Mahardika, Ahmad Gelora, Urgensi Revisi Peraturan Pemerintah Pengganti UndangUndang Nomor 23 Tahun 1959 sebagai Konstekstualisasi Iklim Demokrasi, Justitia Jurnal Hukum Universitas Muhammdiyah Surabaya, Volume 4, No 2 Oktober 2020 pp. 371-372.

[14] Lebret, Audrey, COVID-19 Pandemic and Derogation to Human Rights, Jurnal of Law and Biosciences, 2020, p.4.

[15] Budiardjo, Miriam. (2008). Dasar-dasar Ilmu Politik. Jakarta, Indonesia: Gramedia Pustaka Utama.

[16] Nickel, James W. (1996). Hak Asasi Manusia, Making Sense of Human
Rights: Refleksi Filisofis atas Deklarasi Universal Hak Asasi Manusia, diterjemahkan oleh Titis Eddy Arini. Jakarta, Indonesia: Gramedia Pustaka Utama.

[17] Criddle, Even J. Human Rights Emergencies and the Rule of Law, Human Rights Quartely, April 2010, p.9.

[18] Sheeran, Scott P., Reconceptualizing State of Emergency Under International Human Rights Law, Legal Doctrine and Politics, Michigan Journal of International Law, Volume 34, Issue 3, 2013, p. 499 